\title{
Renoprotective effect of inhibiting renin- angiotensin-aldosterone system (RAAS) by captopril versus losartan on drug- induced acute kidney injury (AKI)
}

\author{
Muhammad Zafar ${ }^{1 *}$, Iram Mushtaq ${ }^{2}$, Muhammad Zahid Khan ${ }^{3}$, \\ Muhammad Khalil Ahmad Khan ${ }^{4}$ and Asmatullah ${ }^{5}$ \\ 1. Post-Graduate Department of Zoology, Government Emerson College, Bosan Road, Multan (MZ)-Pakistan \\ 2. Department of Pathology, University of Veterinary and Animal Sciences, Lahore (IM)-Pakistan \\ 3. House Officer, Medical Unit 04, Bahawal Victoria Hospital and Quid-e-Azam Medical College, Bahawalpur \\ (MZK)-Pakistan \\ 4. Department of Zoology, Government Dial Singh College, Lahore (MKAK)-Pakistan \\ 5. Department of Zoology, University of The Punjab, Quid-e-Azam Campus, Lahore-Pakistan \\ *Corresponding author's email: m.zafar1214@gmail.com \\ Citation \\ Muhammad Zafar, Iram Mushtaq, Muhammad Zahid Khan, Muhammad Khalil Ahmad Khan and Asmatullah. \\ Renoprotective effect of inhibiting renin-angiotensin-aldosterone system (RAAS) by captopril versus losartan on \\ drug-induced acute kidney injury (AKI). Pure and Applied Biology. Vol. 7, Issue 2, pp443-454.
} http://dx.doi.org/10.19045/bspab.2018.70055

Received: $24 / 01 / 2018$

Revised: $26 / 03 / 2018$

Accepted: 28/032018

Online First: $31 / 03 / 2018$

\section{Abstract}

Acute kidney injury (AKI) is a common health problem especially the drug induced AKI is a side or toxic effect during treatment of different medical disorders. The present study was aimed to investigate the renoprotective effect of inhibiting renin-angiotensin-aldosterone system (RAAS) by captopril versus losartan on drug induced acute kidney injury (AKI). In this study sixty (60) male albino rats divided into six groups (10 rats/group); control, AKI. AKI+captopril, AKI+losartan, captopril and losartan have been used. GFR (glomerular filteration rate) and SBP (systolic blood pressure) have been measured. For measurement of MCP-1 (monocyte chemoattractant protein-1), urea, NGAL (Neutrophil gelatinase associated lipocalin, ICAM-1 (intercellular adhesion molecule -1), cystatin-C and creatinine serum samples were collected. Kidney tissues for measurement of tissue of KIM-1 (Kidney injury molecule-1), MDA (malondialdehyde) and renal expression of megalin were removed. Both losartan and captopril attenuated drug induced acute kidney injury (AKI) as revealed from the measured tissue parameters and serum. As compared to losartan, captopril was found to be superior on normalizing KIM-1, megalin and ICAM-1 while as compared to captopril, losartan improved more GFR. In AKI, groups treated with captopril and groups treated with losartan showed no significant difference in such type of measured parameters. Both are used for acute kidney injury and losartan slow the rate of progression of the experimental renal disease as compared to captopril in future case.

Keywords: Acute Kidney Injury (AKI); Captopril; Losartin; Glomerular Filtration Rate (GFR); Malandialdehyde (MDA)

\section{Introduction}

The kidneys are known as susceptible to toxic damage and ischemic because they receive
$22 \%$ of the cardiac output. In the kidneys certain medications are concentrated secondary to tubular reabsorption or 
secretion which can predispose patients for renal injury. Acute renal failure (ARF) can develop due to pre-renal, post renal or intrinsic renal causes [1].

AKI (Acute Kidney Injury) which is characterized due to rapid loss of the ability of the kidneys to concentrate urine, excrete wastes, maintain fluid balance and conserve electrolytes [2]. The RAAS (Renin Angiotensin Aldosterone System) was considered as an endocrine system with angiostensinogen which is produced by the liver that is cleaved by renin and released from the cells of renal juxtaglomerular. By this way AngI (angiotensin I) is generated which in turn is further cleaved by $\mathrm{ACE}$ (Angiotensin Converting Enzyme) activity of the lungs into AngII (Angiotensin II) active form.

Then in the adrenal cortex Ang II binds to specific receptors and resulting in the release of aldosterone. In this way in the collecting duct, the cardinal function of the renin angiotensin aldosterone system (RAAS) is maintaining of blood pressure due to Ang IIinduced aldosterone - mediated sodium retention and vasoconstriction [3].

Local the renin angiotensin aldosterone system (RASS) has been described to operate independently due to their systemic counterpart. In the proximal tubular cells of the kidney a local RAAS including all of its components could have been shown. Proximal tubular cells actively secrete angiotensinogen into the urine and also produce Angiotensin II (Ang II). In the distal tubule, intraluminal angiotensinogen may be converted into Angiotensin II (Ang II) and onservations suggest that it leads towards the induction of sodium channels which are independent of aldosterone. Directly or indirectly, renal injury activates the local renin angiotensin aldosterone system (RAAS) [4].

The present study was aimed to evaluate and compare the renoprotective effects of inhibiting renin angiotensin aldosterone system (RAAS) by losartan versus captapril on AKI (Acute Kidney Injury).

\section{Materials and methods}

\section{Design study}

Sixty (60) male albino rats of four (4) months old weighing 130-160gms constituted the animal model in this study. Rats were housed five (5) per cage with room temperature $25 \pm 2^{0} \mathrm{C}$. These rats were kept under the standard protocol of 12 hour day and night (light/dark) cycles, in 14"X20" steel cages and had free access to water and food. The rats were fed upon commercially prepared chick feed pellets (Chick Feed No.3, Punjab Poultry Feed Pvt. Limited). This feed was further enriched with vitamins (Optilets-M, Abbott Laboratories (Pakistan) Limited) before it was supplied to the animals. Followed ethical recommendations which had been approved by the local scientific and ethical committee, the animals were handled and experimental steps and scarification were done.

\section{Experimental groups / procedure}

All animals were divided into six (6) groups (10 rats / group).

1. Group 1 was known as control group which received salive water through intraperitoneal (i.p) injection for 15 days.

2. Group II was known as Gentamicin group (also known as Acute Renal Failure (ARF) group) which received gentamicin (garamicin, 80mg Sandoz GMP, Switzerland) through intraperitoneal (i.p) injection as $100 \mathrm{mg} / \mathrm{kg} /$ day for 15 days [5].

3. Group III was known as losarton group which received per oral by oral gavage (losartan, Hikma Pharmaceutical PLC, Jordan) as $10 \mathrm{mg} / \mathrm{kg} /$ day for 15 days [5].

4. Group IV was known as Acute Renal Failure (ARF) and losartan group (ARF+losartan) which received injection of $100 \mathrm{mg} / \mathrm{kg} /$ day gentamicin and oral losartan of $10 \mathrm{mg} / \mathrm{kg} /$ day for 15 days [5]. 
5. Group V was known as captapril group which received captopril as $10 \mathrm{mg} / \mathrm{kg} /$ day per oral by oral gavage (Capoten, 25mg, Pharmadex, American) for 15 days [6].

6. Group VI was known as Acute Renal Failure (ARF) and captapril group which receive injection of gentamicin $100 \mathrm{mg} / \mathrm{kg} /$ day and oral captopril of $10 \mathrm{mg} / \mathrm{kg} /$ day for 15 days [6].

At the end of the study all experimental animals were weighted. These experimental male albino rats were placed in steel cages for the period of 24 hours urine collection. Volume of the urine was also measured and then centrifuged for the separation of debris. At $-80^{\circ} \mathrm{C}$ the urine samples were kept until further analysis.

\section{Determination of Glomerular Filtration Rate (GFR)}

After collection of urine for the period of 24 hours and taking the body weight glomerular filteration rate (GFR) was calculated with the help of the following formula [7].

GFR $(\mathrm{ml} / \mathrm{min} / \mathrm{kg})=$ urinary creatinine $(\mathrm{mg} / \mathrm{dl})$ x urine volume $(\mathrm{ml}) \times 1000(\mathrm{gm}) /$ plasma creatinine $(\mathrm{mg} / \mathrm{dl}) \mathrm{x}$ body weight (gm) x 1440 (min).

In the studied groups systolic blood pressure was measured. Then by either inhalation all these albino rats were anesthetized and for the measurement of cystatinc $\mathrm{C}$, serum urea, Monocyte Chemoattractant Protein-I (MCPI), Neutrophil gelatinase-associated lipocalin (NGAL), Inter cellular Adhesion Molecule I (ICAM-I) and creatinine the blood is withdrawn from retroorbital venous sinuses. For the measurement of tissue MDA (Malondialdehyde), KIMI (Kidney Injury Molecule) and renal expression of Megalin, Animals were sacrificed and kidneys were removed.

\section{Measurement of Arterial Systolic Blood Pressure (ASBP)}

At $30^{\circ} \mathrm{C}$ in the tail cuff method, the animals were warmed for 35 minutes in a thermostatically controlled heating cabinet (Ugo Basille, Italy). For better experimental detection of pulse of tail artery, the tail was passed with the help of a miniaturized cuff and a sensor of a tail-cuff that was attached to an amplifier (ML 130 NIBP, AD Instruments, Australia) [8].

In albino male rats for the measurement of systolic blood pressure (SBP) the tail cuff is known as a common and convenient noninvasion method. Through this the tail cuff first of all is inflated and then deflated. When the cuff is inflated pulsations will be disappear and when the cuff is deflated pulsations will start appearing and then the pressure in the cuff will be equal to the systolic pressure. So the cuff will be attached to a tail cuff sphygmomanometer and blood pressure (BP) will be recorded on a chart [9]. With the help of a non-invasive blood pressure (BP) monitor (model ML 130 NIBP, AD Instruments Pty. Ltd., Sydney, Australia) systolic blood pressure (SBP) and heart rate of animals were indirectly measured each week from the tail of conscious rats through the tail-cuff method for which all animals were pre-trained until blood pressure (BP) was steadily recorded with restrained and minimal stress. By the method described by [8] training was conducted. Cuff deflation pressure (Systolic Blood Pressure (SBP)) was defined as the point through which the cuff pressure is corresponded to the restoration of the first pulse of caudal artery. On each occasion the average of at least three readings (measurements) was taken. By a counter triggered through the pulse wave heart rate was automatically recorded.

\section{Biochemical Measurements/Real-Time RT-PCR (Reversal Transcriptase Polymerase Chain Reaction)} Using the SV Total RNA Isolation Kit (Promega, Madison WI) total RNA was isolated from kidney tissue through the manufacturer's instructions including a treatment step of DNAase. According to 
manufacturer's protocol by using the Superscript II Reverse Transcriptase Kit (Invitrogen) / ug of RNA was then reverse transcribed into complementary DNA (cDNA). By using emission from SYBR Green (SYBR Green Master Mix, Applied Biosystems), amplification and detection were performed in an optical 98-well plate with an ABI PRISM 7600 fast sequence detection system (Applied Biosystems, Carlsbad, California). PCR cycles which were consisted of 40 cycles at $95^{\circ} \mathrm{C}$ for 15 minutes and $60^{\circ} \mathrm{C}$ for 60 seconds after an initial activation step at $50^{\circ} \mathrm{C}$ for two minutes and a hot start at $95^{\circ} \mathrm{C}$ for ten minutes. The sequence of Polymerase Chain Reaction (PCR) primer pairs used are shown in Table 1. Data were analyzed through the detection system of ABI Prism Sequence Software quantified by using the version of 1.7 Sequence Detection Software from PE Biosystems (Foster City, CA). By using the comparative threshold cycle method relative expression of studied genes was to be calculated. All values were normalized to the glyceraldehydes-3-phosphate dehydrogenase (GADDH) which was used as the source of the control housekeeping gene [10].

\section{Estimation of Malandialdehyde (MDA)}

In kidney tissues, lipid peroxidations were estimated through measurement of TBARS (Thiobarbituric acid reactive substances) with the help of method of [11]. To $0.2 \mathrm{ml}$ of the sample, $0.9 \%$ TBA and $22 \%$ acetic acid were added. Then mixture of pyridine was added and after that the contents were vortexed thoroughly for the period of two minutes. At 3000rpm after centrifugation for the period of ten minutes the upper most layer was taken and its OD was read at 534nm. The lipid peroxides levels were expressed as millimoles of TBARS/mg protein i.e. thiobarbituric acid reactive substances / $\mathrm{mg}$ protein.
MCP-I, Serum Cystatin, lipocalin and CAMA were detected through ELISA kit (supplied by $\mathrm{R}$ and D System, USA) according to the instructions by manufacturer.

Serum, serum urea and urine creatinine were measured with the help of colorimetric methods according to the instructions by manufacturer (Bio Assay System, USA).

\section{Statistical analysis}

By using the statistical package SPSS version 21 (IBM SPSS Statistics 21, IBP Corporation, New York, USA) data were coded and entered for Microsoft Windows. With the help of means and standard deviation data was summarized. By using ANOVA-1(Analysis of Variance-1) comparisons between groups were done with multiple comparisons of Post Hoc Bonferroni test. Probability values (P-Values) less than 0.05 were considered to be as statistically insignificant [12].

\section{Results}

In AKI group compared to the control group a significant $(\mathrm{P} \leq 0.05)$ increase of systolic blood pressure was to be found. Similarly administration of either captopril or losartan in AKI (acute kidney injury) groups showed significant $(\mathrm{P} \leq 0.05)$ decrease of SBP (Systolic Blood Pressure) as compared to that of untreated AKI group. In SBP (Systolic Blood Pressure) in AKI (acute kidney injury) groups which were treated with captopril or losartan showed no significant difference.

In AKI (acute kidney injury) group GFR (glomerular filtration rate) was found to be significantly $(\mathrm{P} \leq 0.05)$ decreased as compared to the control group. Similarly, captopril or losartan therapy showed significantly $(\mathrm{P} \leq 0.05)$ increased GFR glomerular filtration rate) as compared to untreated AKI (Acute Kidney Injury) group. Significant $(\mathrm{P} \leq 0.05)$ increase of GFR (glomerular filtration rate) showed by losartan as compared to AKI (acute kidney injury) group which was treated with captopril. 
Table 1. Primer Sequences used for Reverse Transcriptase Polymerase Chain Reaction (RTPCR)

\begin{tabular}{|l|l|}
\hline Primer & Sequence \\
\hline KIM-I & $\begin{array}{l}\text { Forward Primer 5' - AGAGAGAGCAGGACACAGGCTT - 3' } \\
\text { Reverse Primer 5' - ACCCGTGTAGTCCCAAACA - 3' }\end{array}$ \\
\hline GAPDH & $\begin{array}{l}\text { Forward Primer 5' - GATGCTGGTGCTGAGTATGTCG - 3' } \\
\text { Reverse Primer 5' - GTGGTGCAGGATGCATTGCTCTGA -3' }\end{array}$ \\
\hline Megalin & $\begin{array}{l}\text { Forward Primer 5' - GATGCTGTTGCTGGCGATCG - 3' } \\
\text { Reverse Primer 5' - GCATTGTCACAGCGAAAATTCCCAC - 3' }\end{array}$ \\
\hline
\end{tabular}

In AKI (Acute Kidney Injury) group as compared to the control group a significant $(\mathrm{P} \leq 0.05)$ increase of serum urea, cystatin, NGAL, MCP-1, creatinine and ICAM-1 in AKI (Acute Kidney Injury) group was to be found. Captopril or losartan therap in AKI (Acute Kidney Injury) group showed a significant $(\mathrm{P} \leq 0.05)$ decrease of serum urea, MCP-1, NGAL, ICAM-1, cystatin and creatinine compared to AKI (Acute Kidney Injury) group. Similarly, no significant difference was to be found in most of the measured serum parameters in protective effect offered by captopril versus losartan except for ICAM-1 which showed significant $(\mathrm{P} \leq 0.05)$ decrease in AKI (Acute Kidney Injury) group treated with losartan to AKI (Acute Kidney Injury) group treated with captopril (Table 2).

Significant $(\mathrm{P} \leq 0.05)$ increase of renal expression of KIM-1 and MDA was showed by AKI (Acute Kidney Injury) group as compared to that of control group. Administration of captopril or losartin with AKI (Acute Kidney Injury) group showed a significant $(\mathrm{P} \leq 0.05)$ decrease of KIM-1 and
MDA expression as compared to that of AKI (Acute Kidney Injury) group. No significant difference was to be found in MDA expression in AKI (Acute Kidney Injury) groups with losartan versus AKI (Acute Kidney Injury) group which received captopril, however, significant $(\mathrm{P} \leq 0.05)$ reduction showed by KIM-1 expression in AKI (Acute Kidney Injury) group to which was treated with captopril as compared to AKI (Acute Kidney Injury) group which received losartan (Table 3 ).

In AKI (Acute Kidney Injury) group as compared to control group megalin expression was found to be significantly $(\mathrm{P} \leq 0.05)$ decreased. Administration of captopril or losartan to AKI (Acute Kidney Injury) groups showed a significant $(\mathrm{P} \leq 0.05)$ increase of megalin expression as compared to that of untreated AKI (Acute Kidney Injury) group. In AKI (Acute Kidney Injury) group, captopril treatment showed a significant $(\mathrm{P} \leq 0.05)$ increase of megalin expression as compared to that of AKI (Acute Kidney Injury) group treated with that of losartan (Table 3). 
Table 2. Studied Groups shown by Biochemical Parameters Measured in Serum.

\begin{tabular}{|c|c|c|c|c|c|c|}
\hline & $\begin{array}{l}\text { Control } \\
(n=10 \text { rats } \\
\text { ) }\end{array}$ & $\begin{array}{l}\text { AKI } \\
(n=10 \text { rats })\end{array}$ & $\begin{array}{l}\text { AKI } \\
\text { +Captopril } \\
\text { (n=10rats) }\end{array}$ & $\begin{array}{l}\text { AKI } \\
+ \text { Losartan } \\
\text { (n=10rats) }\end{array}$ & $\begin{array}{l}\text { Losartan } \\
(n=10 \text { rats })\end{array}$ & $\begin{array}{l}\text { Captopril } \\
(n=10 \text { rats })\end{array}$ \\
\hline $\begin{array}{l}\text { Urea } \\
\text { (mg/dl) }\end{array}$ & $\begin{array}{l}37.70 \pm 11 . \\
92\end{array}$ & $\begin{array}{l}90.28 \pm 7.86 \\
*\end{array}$ & $\begin{array}{l}55.35 \pm 10.06 \\
* \#\end{array}$ & $\begin{array}{l}51.33 \pm 8.87 * \\
\#\end{array}$ & $\begin{array}{l}39.67 \pm 4.77 \\
\# \$\end{array}$ & $\begin{array}{l}43.27 \pm 7.21 \\
\# \$\end{array}$ \\
\hline $\begin{array}{l}\text { Cystatin } \\
\text { (mg/dl) }\end{array}$ & $0.76 \pm 0.19$ & $3.72 \pm 2.48 *$ & $2.29 \pm 0.58 \#$ & $2.50 \pm 0.47 \#$ & $0.90 \pm 0.31 \#$ & $0.86 \pm 0.22 \#$ \\
\hline $\begin{array}{l}\text { Creatini } \\
\text { ne } \\
(\mathrm{mg} / \mathrm{dl})\end{array}$ & $0.15 \pm 0.07$ & $1.55 \pm 0.58 *$ & $0.70 \pm 0.25 * \#$ & $0.69 \pm 0.22 * \#$ & $\begin{array}{l}0.16 \pm 0.08 \# \\
\$\end{array}$ & $\begin{array}{l}0.16 \pm 0.08 \# \\
\$\end{array}$ \\
\hline $\begin{array}{l}\text { NGAL } \\
\text { (ng/dl) }\end{array}$ & $\begin{array}{l}152.99 \pm 4 . \\
6\end{array}$ & $\begin{array}{l}218.5 \pm 12.6 \\
4 *\end{array}$ & $\begin{array}{l}119.07 \pm 30.6 \\
3 \#\end{array}$ & $\begin{array}{l}135.44 \pm 32.9 \\
2 \#\end{array}$ & $110.61 \pm 8.9$ & $\begin{array}{l}104.18 \pm 6.8 \\
8\end{array}$ \\
\hline $\begin{array}{l}\text { ICAM-1 } \\
\text { (pg/ml) }\end{array}$ & $\begin{array}{l}139.6 \pm 7.7 \\
3\end{array}$ & $\begin{array}{l}190.3 \pm 17.4 \\
8 *\end{array}$ & $\begin{array}{l}39.771 \pm 7.66 \\
* \# \$\end{array}$ & $\begin{array}{l}57.94 \pm 8.49 * \\
\#\end{array}$ & $37.37 \pm 7.08$ & $35.09 \pm 6$ \\
\hline $\begin{array}{l}\text { MCP-1 } \\
(\mathrm{pg} / \mathrm{ml})\end{array}$ & $\begin{array}{l}39.17 \pm 3.3 \\
6\end{array}$ & $\begin{array}{l}107.6 \pm 24.0 \\
8 *\end{array}$ & $\begin{array}{l}50.70 \pm 16.25 \\
\#\end{array}$ & $\begin{array}{l}59.23 \pm 17.99 \\
\#\end{array}$ & $36.4 \pm 6.776$ & $33.36 \pm 4.83$ \\
\hline
\end{tabular}

*: statistically significant compared to corresponding values in the control group.

$\$$ : statistically significant compared to corresponding value in AKI (Acute Kidney Injury) + losartan group at $\mathrm{P} \leq 0.05$. \#: statistically significant compared to corresponding value in AKI (Acute Kidney Injury) group.

AKI (Acute Kidney Injury)

ICAM-1 = Intercellular Adhesion Molecule 1

MCP = Monocyte Chemo-attractant Protein 1

NGAL $=$ Neutrophil Gelatinase Associated Lipocalin

Table 3. Studied Groups Show Biochemical Parameters measured in Kidney Tissue.

\begin{tabular}{|c|c|c|c|c|c|c|}
\hline & $\begin{array}{l}\text { Control } \\
(n=10 \text { rats })\end{array}$ & $\begin{array}{l}\text { AKI } \\
(n=10 \text { rats })\end{array}$ & $\begin{array}{l}\text { AKI } \\
+ \text { Captopril } \\
\text { (n=10rats) }\end{array}$ & $\begin{array}{l}\text { AKI } \\
+ \text { Losartan } \\
(n=10 \text { rats })\end{array}$ & $\begin{array}{l}\text { Losartan } \\
(\mathrm{n}=10 \mathrm{rats})\end{array}$ & $\begin{array}{l}\text { Captopril } \\
(\mathrm{n}=10 \mathrm{rats})\end{array}$ \\
\hline $\begin{array}{l}\text { Megalin } \\
\text { (Relative } \\
\text { Expression } \\
\text { ) }\end{array}$ & $\begin{array}{l}0.27 \pm 0.16 \\
6\end{array}$ & $\begin{array}{l}0.160 \pm 0.5 \\
0 *\end{array}$ & $\begin{array}{l}0.99 \pm 14 * \# \\
\$\end{array}$ & $\begin{array}{l}0.30 \pm 0.14 \\
\#\end{array}$ & $1.6 \pm 0.45$ & $1.42 \pm 0.6$ \\
\hline $\begin{array}{l}\text { KIM } \\
\text { (Relative } \\
\text { Expression } \\
\text { ) }\end{array}$ & $8.05 \pm 4.2$ & $\begin{array}{l}13.6 \pm 1.57 \\
7 *\end{array}$ & $\begin{array}{l}2.43 \pm 1.47 \\
2 * \# \$\end{array}$ & $\begin{array}{l}6.06 \pm 2.15 \\
8 * \#\end{array}$ & $\begin{array}{l}1.31 \pm 0.42 \\
8\end{array}$ & $1.31 \pm 0,27$ \\
\hline $\begin{array}{l}\text { MDA } \\
(\mathrm{mmol} / \mathrm{mg})\end{array}$ & $3.1 \pm 4.27$ & $8.8 \pm 4.67 *$ & $\begin{array}{l}2.782 \pm 1.2 \\
4 * \#\end{array}$ & $\begin{array}{l}5.6 \pm 1.477 \\
* \#\end{array}$ & $\begin{array}{l}1.28 \pm 0.44 \\
848\end{array}$ & $1.77 \pm 0.789$ \\
\hline
\end{tabular}

*: statistically significant compared to corresponding values in the control group.

$\$$ : statistically significant compared to corresponding value in ARF (Acute Renal Failure) + losartan group at $\mathrm{P} \leq 0.05$. \#: statistically significant compared to corresponding value in ARF (Acute Renal Failure) group.

MDA = Malondialdehyde

AKI $=$ Acute Kidney Injury

KIM-1 = Kidney Injury Molecule -1

\section{Discussion}

AKI (Acute Kidney Injury) is known as a common health problem particularly the drug induced AKA as a toxic or side effect during the treatment of several medical disorders. In different tissues and organs the existence of 
independent RAAS (Renin Angiotensin Aldosterone System) has been reported. In the kidney, all components of the renal RAAS (Renin Angiotensin Aldosterone System) which are produced being completely independent of the RAAS (Renin Angiotensin Aldosterone System) and contribute to the progression of both chronic and acute diseases of kidney [13]. In the current study at two different levels we have to evaluate the renoprotective effect of blocking RAAS (Renin Angiotensin Aldosterone System); by AII receptor blocker (ARB) losartan and by ACEI (Angiotensin converting enzyme inhibitor).

The results through this study showed renoprotective effects of both losartin and captopril in AKI (Acute Kidney Injury) which as revealed from their effects on glomerular filtration rate (GFR), blood pressure, tissue parameters and measured serum. Regarding some of the measured biochemical parameters captopril effect was found to be superior as compared to the losartan. However, on glomerular filtration rate (GFR) losartan had a better effect.

According to our results, [14] found that losartan and captopril slow the rate of progression of experimental diseases of kidney.

For the progression of kidney diseases increased AII activity was found to be as a risk factor. Increasing clinical evidence has been found due to the combining of angiotensin converting enzyme inhibitor (ACEI) with AII receptor blocker (ARB) which reduces blood pressure and protein urea in patients captured with renal diseases [15]. For the development of contrast-induced nephrotoxicity, the abnormalities of renal perfusion which are mediated by the RAAS (Renin Angiotensin Aldosterone System) are responsible.

Administration of the ACEI (angiotensin converting enzyme inhibitor), captopril, offers protection against the development of CIN (Contrast Induced Nephrotoxicity) [16].
With response to our results, [17] reported that on endogenous levels of angiotensin losarton has specific tissue effects. Furthermore, [18] in a study reported that losartan decreased blood cystaxin $\mathrm{C}$ levels and attenuated tubular necrosis, inflammatory cell infiltration and renal fibrosis.

In some study of two years course of antihypertensive therapy with either captopril or losartan showed significantly reduced UAC (Urinary Albumin Creatinine) ratio in the patients of type II diabetic during early nephropathy. With each treatment the reduction in urinary albumin creatinine (UAC) is similarly related to that of acute blood pressure (ABP) [19]. In patients with type II diabetes and nephropathy losartan conferred significant renal benefits and it was generally well tolerable [20].

Cystatin $\mathrm{C}$ is known as a 122 amino acid with low molecular weight protein belongs to the member of cysteine proteinase inhibitors [21]. By all nucleated cells it is produced at a constant rate. It is freely filtered through glomerular, reabsorbed and then catabolized while not secreted through the renal tubules [21]. Cystatin $\mathrm{C}$ is also known as the most sensitive indicators of nephrotoxicity [22]. Unlike creatinine its serum concentration appears to be the most independent of sex, muscle mass and age [23].

In most nephrons inhibition of the RAAS (Renin Angiotensin Aldosterone System) or AII receptor blocker (ARB) represents to a reversible reduction process in intraglomerular pressure. For the maintenance of renal function the remnant nephrons are present which function at a higher baseline pressure [24].

Monocyte Chemoattractant Protein-1 (MCP1) belongs to a chemokine family and is known as a potent chemotactic factor for monocytes [25]. MCP-1 was described as an increased expression in experimental and human forms of glomerulonephritis [26]. For mononuclear inflammatory processes the 
MCP-1 is known as a biomarker and acts a mediator of acute ischemic (AC) and toxic kidney injury (TKI) [27].

In glomeruli, MCP-1 expression is increased and tubulointerstitial space associated with Angiotensin II (AngII) dependent hypertension [28]. In vitro in vascular smooth muscle cells Angiotensin II has been shown to increase MCP-1 synthesis [29], while in vivo study in experimental models of immune mediated glomerulonephritis blocked of AngII reduced the induction of MCP-1 [30].

For leukocyte adhesion during the process of inflammation, adhesion molecules are required. Lenkocyte adhesion leads to the extension and inflammation of cellular injury. In pathophysiology of AKI (Acute Kidney Injury), ICAM-1 (Intercellular Adhesion Molecule-1) plays an important role [31].

Deficiency of ICAM-1 not only decreased mentrophil adhesion against LPS-induced ARF (Acute Renal Failure) but also by abrogating signaling stages that occurred upon ligation of ICAM-1 in endothelium [32].

In concerned with our results, RAAS (Renin Angiotensin Aldosterone System) with valsartan in combination with a statin (fluvastatin) in mouse model of atherosclerosis reduced the level of superoxide anion, atherosclerotic lesions and the expression level of ICAM-1 and MCP-1 (Monocyte Chemoattractant Protein-1) indicating that oxidative stress and blocking inflammation has beneficial effects on endothelium [33]. A reduction on cardiovascular stages showed by clinical studies following blood pressure lowering positively altering vascular wall or endothelium structure which indicates reduction of cardiovascular disease. Vascular function and endothelial activity by increasing number bioavailability improved by several RAAS (Renin Angiotensin Aldosterone System) inhibitors such as ARB (Angiotensin II Receptor Blocker) and ACEI (Angiotensin Converting Enzyme Inhibitor) [34].
NGAL (Neutrophil Gelatinase-Associated Lipocalin) belongs to the lipocalin family is a small $25-\mathrm{K}$ Da protein is a biomarker of tubular damage that secretes tubular protein when entered rapidly both in serum and urine after the onset of AKI (Acute Kidney Injury) [35]. Decreased serum neutrophil gelatinaseassociated lipocalin (NGAL) levels in animal models of renal interstitial fibrosis which were treated with ACEI showed [36] in agreement with our study. In patients with diabetic nephropathy which were treated with ARB showed no significant change in urinary neutrophil gelatinase-associated lipacalin (NGAL) by [37].

Malondialdehyde (MDA) is known as a marker of lipid peroxidation. In gentamicininduced acute renal failure [38] have examined the role of lipid peroxidation in accordance with our findings. Aliskiren on AKI (Acute Kidney Injury) induced by ischemia-reperfusion [39] studied the effect of blocking RAAS (Renin Angiotensin Aldosterone System) by direct renin inhibitor and showed decrease of renal and increased of lipid peroxidation MDA after the administration of aliskiren.

Megalin is known as a single transmembrane receptor protein of $600-\mathrm{K}$ da, belongs to the family of low-density lipoprotein, responsible for the normal tubular reabsorption of all types of filtered proteins that mediates the recovery of important substances which otherwise would be lost in the urine [40]. Megalin in the the kidney is expressed in the proximal part and showed much lower level in glomerular podocytes [41]. In different models of AKI (Acute Kidney Injury) different changes in megalin mRNA expression have been demonstrated. A decrease in renal megalin mRNA expression was to be observed AKI (Acute Kidney Injury) and LPS-indcued acute endotoxemia. This type of decrease was found to be associated with that of increased excretion of urinary albumin [42]. 
Renin is known as a ligand for megalin. In its tubular retrieval, partial megalin deficiency is known as substantial urinary renin excretion which shows the role of megalin [13]. In the transcytosis of RAS components a role for megalin has thus been demonstrated [43]. From the ultrafilterate process the early proximal tubule shows very effective, megalin-dependent endocytotic uptake and intracellular storage of AGT and renin [44].

Kidney injury molecule-1 (KIM-1) is known as a Type I transmembrane glycoprotein which is localized in chronic and acute injury in the apical membrane of dilated tubules [45] KIM-1 plays an important role in the processes of regeneration after epithelial injury and through phagocytosis the removal of dead cells in the tubular lumen [46]. In proteinuria a reduction is accompanied through the reduction in urinary KIM-1 (Kidney Injury Molecule-1) excretion with renin-angiotensinaldosterone blocked [47].

In the kidneys of a wide variety of human diseases and in different animal models, KIM1 is upregulated. Into the urine, a large quantity of KIM-1 protein is also shed, making it a useful it a purposeful urinary biomarker for AKI (Acute Kidney Injury) [46]. KIM-1 also performs as a receptor, scavenger and mediates the uptake of modified nectoric cell debris and low-density lipprotein [44].

\section{Conclusion}

Both losartan and captopril attenuated drug induced AKI (Acute Kidney Injury) as concerned from the tissue parameters and measured serum. Captopril was found to be superior to losartan on normalizing megalin, KIM-1 and ICAM-1, however, losartan has improved GFR (glomerular filtration rate) more as compared to that of captopril, while other parameters in AKI (Acute Kidney Injury) groups which were treated with losartan and groups which were treated with captopril showed no significant difference.

For histopathological evaluation of the renal tissue for further examination of the state of medulla and the cortex of the kidney we recommend more studies by other blockers of RAAS (Renin Angiotensin Aldosterone System).

\section{Authors' contributions}

Conceived and designed the experiments: $\mathrm{M}$ Zafar, Performed the Experiment: M Zafar, Analyzed the Data: MKA Khan, I Mushtaq \& MZ Khan, Supervised the Experiment: Asmatullah, Contributed reagents/ materials/ analysis tools: M Zafar, MKA Khan, I Mushtaq, MZ Khan \& Asmatullah, Wrote the paper: M Zafar.

\section{References}

1. Mary TR. Acute Renal Failure: Causes and Treatment.

2. Schrier RW, Wang W, Poole B \& Mitra A (2004). Acute renal failure: definitions, diagnosis, pathogenesis, and therapy. $J$ Clin Invest 114: 5.

3. Wolf G \& Neilson E (1996). From converting enzyme inhibition to angiotensin II receptor blockade: new insight on angiotensin II receptor subtypes in the kidney. Exp Nephrol 4: 8-19.

4. Beutler KT, Masilamani S, Turban S, Nielsen J, Brooks HL, Ageloff S, Fenton RA, Packer RK \& Knepper MA (2003). Long-term regulation of $\mathrm{ENaC}$ expression in kidney by angiotensin II. Hypertension 41: 1143-1150.

5. Heeba GH (2011). Angiotensin II receptor blocker, losartan, ameliorates gentamicininduced oxidative stress and nephrotoxicity in rats. Pharmacology 87: 232-240.

6. Ali B \& Bashir A (1993). Comparative modulating effects of captopril, diltiazem, dietary calcium and pyridoxal-5'-phosphate on gentamicin-induced nephrotoxicity in the rat. General Pharmacology: The Vascular System 24: 1279-1283.

7. Pestel S, Krzykalla V \& Weckesser G (2007). Measurement of glomerular filtration rate in the conscious rat. $J$ Pharmacol Tox Met 56: 277-289. 
8. Irvine RJ, White J \& Chan R (1997). The influence of restraint on blood pressure in the rat. J Pharmacol Tox Met 38: 157-162.

9. Nagura J, Yamamoto M, Hui C, Yasuda S, Hachisu M \& Konno F (1996). Protective effects of me3221 on hypertensive complications and lifespan in salt-loaded stroke-prone spontaneously hypertensive rats. Clin Exp Pharmacol P 23: 229-235.

10. Livak KJ \& Schmittgen TD (2001). Analysis of relative gene expression data using real-time quantitative PCR and the 2- $\Delta \Delta C T$ method. Methods 25: 402-408.

11. Ohkawa H, Ohishi N \& Yagi K (1979). Assay for lipid peroxides in animal tissues by thiobarbituric acid reaction. Anal Biochem 95: 351-358.

12. Altman DG (1990). Practical statistics for medical research, CRC press.

13. Kobori H, Nangaku M, Navar LG \& Nishiyama A (2007). The intrarenal renin-angiotensin system: from physiology to the pathobiology of hypertension and kidney disease. Pharmacol Rev 59: 251-287.

14. Ots M, Mackenzie HS, Troy JL, Rennke HG \& Brenner BM (1998). Effects of combination therapy with enalapril and losartan on the rate of progression of renal injury in rats with 5/6 renal mass ablation. J Am Soc Nephrol 9: 224-230.

15. Komine N, Khang S, Wead LM, Blantz RC \& Gabbai FB (2002). Effect of combining an ACE inhibitor and an angiotensin II receptor blocker on plasma and kidney tissue angiotensin II levels. Am J Kidney Dis 39: 159-164.

16. Gupta R, Kapoor A, Tewari S, Sinha N \& Sharma R (1999). Captopril for prevention of contrast-induced nephropathy in diabetic patients: a randomised study. Ind heart $J$ 51: 521526.

17. Campbell DJ, Kladis A \& Valentijn AJ (1995). Effects of losartan on angiotensin and bradykinin peptides and angiotensin- converting enzyme. J Cardiovasc Pharm 26: 233-240.

18. Wen Z, Cai M, Mai Z, Chen Y, Geng D \& Wang J (2013). Protection of renal impairment by angiotensin II type 1 receptor blocker in rats with postinfarction heart failure. Renal Failure 35: 766-775.

19. Lacourcière $\mathrm{Y}$, Bélanger $\mathrm{A}$, Godin $\mathrm{C}$, Hallé JP, Ross S, Wright N \& Marion J (2000). Long-term comparison of losartan and enalapril on kidney function in hypertensive type 2 diabetics with early nephropathy. Kidney Int 58: 762-769.

20. Brenner BM, Cooper ME, De Zeeuw D, Keane WF, Mitch WE, Parving HH, Remuzzi G, Snapinn SM, Zhang Z \& Shahinfar S (2001). Effects of losartan on renal and cardiovascular outcomes in patients with type 2 diabetes and nephropathy. New Engl J Med 345: 861869.

21. Laterza OF, Price CP \& Scott MG (2002). Cystatin $\mathrm{C}$ : an improved estimator of glomerular filtration rate? Clin Chem 48: 699-707.

22. Hoffmann D, Fuchs TC, Henzler T, Matheis KA, Herget T, Dekant W, Hewitt P \& Mally A (2010). Evaluation of a urinary kidney biomarker panel in rat models of acute and subchronic nephrotoxicity. Toxicology 277: 49-58.

23. Filler G, Bökenkamp A, Hofmann W, Le Bricon T, Martínez-Brú C \& Grubb A (2005). Cystatin $\mathrm{C}$ as a marker of GFRhistory, indications, and future research. Clin Biochem 38: 1-8.

24. Bakris GL, Williams M, Dworkin L, Elliott WJ, Epstein M, Toto R, Tuttle K, Douglas J, Hsueh W \& Sowers J (2000). Preserving renal function in adults with hypertension and diabetes: a consensus approach. Am J kidney Dis 36: 646-661.

25. Deshmane SL, Kremlev S, Amini S \& Sawaya BE (2009). Monocyte 
chemoattractant protein-1 (MCP-1): an overview. J Interf Cytok Res 29: 313-326.

26. Grandaliano G, Gesualdo L, Ranieri E, Monno R, Montinaro V, Marra F \& Schena FP (1996). Monocyte chemotactic peptide-1 expression in acute and chronic human nephritides: a pathogenetic role in interstitial monocytes recruitment. $J \mathrm{Am}$ Soc Nephrol 7: 906-913.

27. Luis AB (2013). Biomarkers of acute kidney injury. J Bras Nephrol 35: 3-5.

28. Karl F, Hilgers, Andrea H \& Markus P (2000). Monocyte chemoattractant protein-1 and macrophage infiltration in hypertensin kidney injury. Kidney Int 58: 2408-2419.

29. Chen XL, Tummala PE, Olbrych MT, Alexander RW \& Medford RM (1998). Angiotensin II induces monocyte chemoattractant protein-1 gene expression in rat vascular smooth muscle cells. Circ Res 83: 952-959.

30. Ruiz-Ortega M, Bustos C, HernándezPresa MA, Lorenzo O, Plaza JJ \& Egido J (1998). Angiotensin II participates in mononuclear cell recruitment in experimental immune complex nephritis through nuclear factor $-\kappa \mathrm{B}$ activation and monocyte chemoattractant protein-1 synthesis. J Immunol 161: 430-439.

31. Molitoris BA \& Marrs J (1999). The role of cell adhesion molecules in ischemic acute renal failure 12. Am J Med 106: 583592.

32. Wang Q \& Doerschuk CM (2000). Neutrophil-induced changes in the biomechanical properties of endothelial cells: roles of ICAM-1 and reactive oxygen species. J Immun 164: 6487-6494.

33. Li Z, Iwai M, Wu L, Liu HW, Chen R, Jinno T, Suzuki J, Tsuda M, Gao XY \& Okumura M (2004). Fluvastatin enhances the inhibitory effects of a selective AT1 receptor blocker, valsartan, on atherosclerosis. Hypertension 44: 758763.
34. Mason RP (2011). Optimal therapeutic strategy for treating patients with hypertension and atherosclerosis: focus on olmesartan medoxomil. Vascular Health and Risk Management 7: 405.

35. Mishra J, Ma Q, Prada A, Mitsnefes M, Zahedi K, Yang J, Barasch J \& Devarajan $P$ (2003). Identification of neutrophil gelatinase-associated lipocalin as a novel early urinary biomarker for ischemic renal injury. J Am Soc Nephrol 14: 25342543.

36. Zhang H, Zhu Y, Jia N, Zhang HT, Zheng J \& Zhu WP (2012). Expression and significance of neutrophil gelatinaseassociated lipocalin in renal interstitial fibrosis in rats. Zhonghua Yi Xue Za Zhi 92: 2565-2569.

37. Nielsen SE, Rossing K, Hess G, Zdunek $\mathrm{D}$, Jensen BR, Parving HH \& Rossing $\mathrm{P}$ (2012). The effect of RAAS blockade on markers of renal tubular damage in diabetic nephropathy: u-NGAL, u-KIM1 and u-LFABP. Scand J Clin Lab Inv 72: 137-142.

38. Ramsammy LS, Josepovitz C, Ling K, Lane BP \& Kaloyanides GJ (1986). Effects of diphenyl-phenylenediamine on gentamicin-induced lipid peroxidation and toxicity in rat renal cortex. $J$ Pharmacol Exp Ther 238: 83-88.

39. Wang Z, Liu Y, Han Y, Guan W, Kou X, Fu J, Yang D, Ren H, He D \& Zhou L (2013). Protective effects of aliskiren on ischemia-reperfusion-induced renal injury in rats. Eur J Pharmacol 718: 160166.

40. Christensen EI, Birn H, Storm T, Weyer K \& Nielsen R (2012). Endocytic receptors in the renal proximal tubule. Physiology 27: 223-236.

41. Prabakaran T, Nielsen R, Larsen JV, Sørensen SS, Feldt-Rasmussen U, Saleem MA, Petersen CM, Verroust PJ \& Christensen EI (2011). Receptormediated endocytosis of $\alpha$-galactosidase 
A in human podocytes in Fabry disease. PloS one, 6: e25065.

42. Schreiber A, Theilig F, Schweda F \& Höcherl K (2012). Acute endotoxemia in mice induces downregulation of megalin and cubilin in the kidney. Kidney Inter 82: 53-59.

43. Christensen EI, Verroust PJ \& Nielsen R (2009). Receptor-mediated endocytosis in renal proximal tubule. Pflügers ArchivEuropean J Physiol 458: 1039-1048.

44. Park S, Binova BJ, Kabori H, Seth DM, Chappell MC, Lazartigues E \& HarrisonBernard LM (2010). Am J Physiol-Renal 298: 37-48.
45. Ichimura T, Asseldonk EJ, Humphreys BD, Gunaratnam L, Duffield JS \& Bonventre JV (2008). Kidney injury molecule-1 is a phosphatidylserine receptor that confers a phagocytic phenotype on epithelial cells. J Clin Invest 118: 1657.

46. Bonventre JV (2009). Kidney injury molecule-1 (KIM-1): a urinary biomarker and much more. Oxford University Press.

47. Waanders F, Van Timmeren MM, Stegeman CA, Bakker SJ \& Van Goor H (2010). Kidney injury molecule-1 in renal disease. J Pathol 220: 7-16. 